\title{
Investigating the impact of project definition clarity on project performance: a Structural Equation Modeling (SEM) Study
}

\author{
Bo XIA ${ }^{1}$, Bo Xiong ${ }^{2}$, Martin Skitmore ${ }^{3}$, Peng $\mathrm{Wu}^{4}$, Fang $\mathrm{Hu}^{5}$ \\ ${ }^{1} \mathrm{PhD}$, Senior Lecturer, School of Civil Engineering and Built Environment, Queensland University of \\ Technology Email: paul.xia@qut.edu.au \\ ${ }^{2} \mathrm{PhD}$ candidate, School of Civil Engineering and Built Environment, Queensland University of Technology \\ Email: peterxiongbo@gmail.com \\ ${ }^{3} \mathrm{PhD}$, Professor, School of Civil Engineering and Built Environment, Queensland University of Technology \\ Email: rm.skitmore@qut.edu.au \\ ${ }^{4} \mathrm{PhD}$, Senior Lecturer, Department of Construction Management, Curtin University, Australia. \\ Email: peng.wu@curtin.edu.au \\ ${ }^{5} \mathrm{PhD}$, Lecturer, Business School, Griffith University \\ Email: f.hu@griffith.edu.au
}

\begin{abstract}
Having a clear project definition is crucial for successful construction projects. It affects design quality, project communication between stakeholders and final project performance in terms of cost, schedule and quality. This study examines the relationship between project definition and final project performance through a structural equation model comprising 4 latent constructs and 6 path hypotheses using data from a questionnaire survey of 120 general contractors in the Malaysian construction industry. The results show that in the study population, all three items impact the project performance, but the link between design quality and project performance is indirect. Instead, the clarity of project definition affects project performance indirectly through design quality and project communication and design quality affects project performance indirectly through project communication. The primary contribution is to provide quantitative confirmation of the more general statements made in the literature from around the world and therefore adds to and consolidates existing knowledge. Practical implications derived from the finding are also proposed for various project stakeholders. Furthermore, as lack of the clarity of project definition is a very common occurrence in construction projects globally, these findings have important ramifications for all construction projects in expanding and clarifying existing knowledge on what is needed for the successful delivery of construction projects.
\end{abstract}

Keywords: project definition, project performance, design quality, project communication, causation, structural equation modeling, Malaysia. 


\section{Background}

Project definition occurs at the first stage of a construction project. This involves the determination of what the owner needs and wants, translation of these needs and wants into design criteria, and generation of a design concept (Ballard and Zabelle, 2000). Project definition provides strategic information for owners to address project risks, maximize the chance of project success, and develop project implementation solutions (Construction Industry Institute, 1995). On the other hand, lack of clarity of project goals, scope and expected outcome is a common source of problems in construction work (Fageha and Aibinu, 2013) and significantly increases the risk of an unsatisfactory outcome for the owner (Quatman and Dhar, 2003; Yu et al., 2006; Wang and Ko, 2012).

Thus, a clear project definition is widely believed to be a key factor for project success (e.g. Songer and Molenaar, 1997; Känkönen, 1999; Christamara et al., 2001; Chan et al. 2001; Cho et al., 2009; Cano and Lidon, 2011). Developing clearly articulated project objectives, requirements and scope in the brief is considered to be the most important competency of owners (Xia and Chan, 2010; Xia et al., 2012a, 2013), and to be treated as a fundamental aspect of project management (Atkinson et al., 2006). This is particularly important for integrated projects, where owners are urged to have a precise understanding of the project scope and clearly articulated end-user needs before communicating them to the contractor (Chan et al. 2001, Xia et al., 2012b, 2012c).

However, in spite of the widely agreed importance of having a clear project definition, few studies have examined this quantitatively. In particular, although a number of sources mention that poor scope definition has a negative impact on project performance (e.g. Song and AbouRizk, 2005; Fageha and Aibinu, 2013), there is no solid evidence to establish a causal relationship between project scope and project performance. Therefore, the aim of this study is to investigate the quantitative impact of project definition on project performance and to construct the causal relationships between the main factors involved.

The paper is organized as follows. First a conceptual framework is developed, from which a set of hypotheses is proposed. Then a structural equation model (SEM) is built from an existing set of data from Masrom (2012) of a questionnaire survey of 120 Malaysian construction contractors. This reveals the underlying interrelationships between project scope 
definition, project performance and other relevant variables. The results show that the clarity of project scope, design quality and project communication impact the project performance, but the link between design quality and project performance is indirect. Additionally, the clarity of project definition affects project performance indirectly through design quality and project communication, and design quality affects project performance indirectly through project communication. Some concluding remarks are provided on the implications for all the stakeholders involved.

\section{Conceptual framework}

The clarity of project definition has a direct impact on project performance. A number of studies point out that poor scope definition can lead to expensive changes, delays, rework, cost overruns, schedule overruns and project failure (Dumont et al., 1997; Cho and Gibson 2001; Song and AbouRizk, 2005; Fageha and Aibinu, 2013). Proper scope definition has been proven a primary determinant of project success in the traditional delivery method, and even more important in design-build integrated projects (Songer and Molenaar 1997). Wang and Huang's (2006) survey of construction supervising engineers in China found scope definition to be significantly correlated with project success. Client-led changes in project scope cause up to $70 \%$ of poor schedule performance in Saudi Arabian projects for example (Assaf and Al-Hejji, 2006).

Project definition also affects design quality and designer performance. When the clarity of project scope increases, owners provide more flexibility and options for designers to develop qualified and innovative design solutions (Xia et al. 2013). Poor performance of designers contributes significantly to delayed government projects in Malaysia (Sambasivan and Soon 2007), and defective designs account for 50\% of quality problems (CIDB 2006). According to Gann et al. (2013), design quality is an important dimension for performance measurement in the U.K., U.S., Australia, Hong Kong and Singapore building and construction sector.

On the other hand, uncertainty in project definition prevents effective communication between project participants (Atkinson et al., 2006). Hence, in view of the widely recognized importance of good communication for successful projects (Project Management Institute, 2000; Keller, 2001), poor project definition will eventually undermine the final project performance. Effective communication can only occur when information about project 
objectives, specifications, priorities and possible constraints are provided (Turner and Muller, 2004). Similarly, clear project definition is important for good design quality and reduces unwarranted design changes, disputes and liability claims (Anumba et al. 1997), which in turn leads to better project performance.

This background suggests a conceptual model of the relationship between the clarity of project definition (PD) and project performance (PP) shown in Figure 1. This comprises four latent constructs and six path hypotheses. The major purpose of this paper is to test the hypothesized relationships in the model. The mediation effects of design quality (DQ) and project communication (PC) are also investigated, as these are useful in reducing the risks of obtaining spurious correlations caused by the lack of a third variable (Judge et al 2001). The following hypotheses are proposed accordingly:

H1: Project definition (PD) has a positive direct effect on project performance (PP)

H2: Project definition (PD) has a positive direct effect on design quality (DQ)

H3: Design quality (DQ) has positive direct effects on project performance (PP).

H4: Project definition (PD) has a positive direct effect on project communication (PC)

H5: Project communication (PC) has a positive direct effect on project performance (PP).

H6: Design quality (DQ) has a positive direct effect on project communication (PC)

\section{Please insert Fig $<1>$ here}

\section{Research methods}

Structural equation modeling (SEM) is used to test the conceptual model and the corresponding hypotheses. Regarded as the most important statistical technique in social sciences in recent decades, SEM is widely used to explore and test relationships between different constructs in the social sciences (Hair et al. 2012). A structural equation model includes observed variables and latent variables that are hard to observe directly due to their abstract character and are represented by using several observed variables (Byrne 2010). As a second-generation multivariate analysis method, SEM has many strengths, such as enabling the use of one model to explore an entire set of complex relationships, or the use of several 
observable items to represent ambiguous constructs (Cho et al. 2009; Fornell and Larcker 1987; Keline 2005).

The measurement framework in Table 1 is based on Keline's three-variable principle, where three observed variables are used to reflect a latent variable to assure identification of the measurement model and retain model parsimony (Keline 2005). The observed variables for project definition, design quality, project communication and project performance are extracted from Masrom's (2012) large postal questionnaire of 120 Malaysian general contractors, formerly used to develop a multiple regression contractor satisfaction model from 95 potential contributing factors. These observed variables, as part of the 95 contributing factors, were identified from literature review (see main sources in Table 1). The project performance is measured in terms of cost, time, and quality (Q10-12), the dominant triple bottom line measurement for construction projects. For the project definition (PD), a high quality project brief that clearly defines owners' needs and requirements (Q1) is of great importance to project success (e.g. Känkönen 1999; Ayman et al., 2004; Atkinson et al. 2006; Park 2009). In addition, the completeness and certainty of project brief (Q2 and Q3) help to reduce the project uncertainty and lead to better project control and final project performance (e.g. Känkönen 1999; Assaf and Al-Hejji 2006; Atkinson et al. 2006; Cho et al., 2009). The design quality (DQ) involves three key attributes (Q4-Q6) namely design constructability, comprehensiveness of design, and flexibility of design (Park 2009; Cho et al., 2009; Masrom 2012). The constructability of design will affect the project success as many design decisions made in the early design stage have significant impacts on the project construction (Pulaski and Horman 2005). Meanwhile, a complete design solution without compromising the flexibility of design for changes is important for whole life project success (Alshawi and Underwood 1996; Park 2009; Cho et al., 2009; Masrom 2012). Project communication (PC) comprises the attributes associated with two way communication between participants (Q7), collaborative work between participants (Q8) and quality of relationship between subcontractors and major contractors (Q9) (Tang et al., 2003; Soetanto and Proverbs, 2004; Cheng et al., 2006; Yang and Peng 2008). It has been widely accepted that effective communication and collaboration between different project participants (e.g. project owners, major contractors, subcontractors, design consultants, etc.) contribute significantly to the project success (Belout and Gauvreau 2004). 
For the observed variables of project definition (Q1-Q3), design quality (Q4-Q6), and project communication (Q7-Q9), the respondents were required to recall a most recently completed construction project where they involved and rate the level of these variables/attributes based on a 5 Likert rating scale from 1=very low to 5= very high and $0=$ "Don't know”. A typical question is "Based on experience from your previous project, at what level would you rate the following attributes?” For the variables of project performance (Q10-Q12), given that it is difficult to obtain the real project performance data, the respondents were required to rate the project performance level based on their satisfaction levels from 1=extremely dissatisfied to $5=$ extremely satisfied and $0=$ "Don't know". The typical question is "Based on the following criteria, please indicate your overall satisfaction level toward that project”.

\section{Please insert Table $<1>$ here}

\section{Results}

\section{Sample descriptions}

Of the 120 respondents, majority have more than 5 years working experience in the industry and $44.2 \%$ respondents hold top management positions in their organizations. The dominant project procurement type is traditional design-bid-build (DBB) and around half of respondents are from large companies (Table 2). To examine whether it is necessary to do multiple group analyses in SEM, principal component analysis (PCA) and analysis of variance (ANOVA) were used. In detail, PCA was applied to extract PD, DQ, PC, PP in Q13, Q4-6, Q7-9 and Q10-12 respectively. Only one principal component was qualified to be extracted in these tests and the suitability was confirmed with Kaiser-Mayer-Olkin (KMO) values higher than 0.5 (Hair 2006) and a highly significant $p<0.0001$ for Bartlett's test for sphericity. As values of the four extracted components are not significantly influenced by project size and procurement methods $(p>0.05)$ as shown in Table 3 , it is acceptable to analyze the sample as a whole across different project sizes and procurement methods. Therefore, the sample size is sufficient for SEM (Bagozzi and Yi, 2012) and the bootstrap technique was also used to help in improving the reliability of the results (Keline, 2005; Cheung and Chow, 2011; Chen \& Fong, 2012). 
Please insert Table $<2>$ here

\author{
Please insert Table $<3>$ here
}

\title{
Normality and reliability assessments
}

It is first necessary to assess the suitability of the data for SEM. Here, we use normality and reliability tests to do this, as severe departures from normality can lead to problems such as inflated model fit statistics (MacCallum et al., 1992) and poor reliability causes inconsistent measurement results. The method of moments provides a reasonable indication of closeness to normality, and Hair et al (2012) suggest a good rule of thumb to be the standardized third and fourth moments (skewness and kurtosis statistics) falling in the $[-1,+1]$ interval. For the Masrom data, the skewness values of all the 12 variables involved range from -0.906 to 0.101 , and the kurtosis values are from -0.166 to 1.141 , with 2 variables slightly more peaked than normal distribution. Chronbach's alpha statistic is used to assess the consistency of the hypothesized constructs, with a value exceeding 0.7 being regarded as acceptable (Cho et al. 2009). As shown in Table 4, the items measured in four variables and the overall construct satisfy the consistency criterion.

Asymptotically distribution-free estimation methods in SEM are available for situations where major departures from multivariate normality occur, but the most common estimation method, maximum likelihood (ML), is known for its robustness in the face of moderate violation of normality (Shah \& Goldstein, 2006) and having more informative model fit statistics and is therefore chosen for the analysis.

\section{Please insert Table $<4>$ here}

\section{Model development and model fit evaluation}

Confirmatory factor analysis (CFA)

Next, a confirmatory factor analysis (CFA) similar to Xiong et al (2014) is carried out to correlate all the predefined constructs and assess the convergent validity. This is done by model fit tests to establish if the correlations between the constructs can be replaced with the 
proposed causal relationships. One such test involves obtaining the standardized regression weights and squared multiple correlations (SMCs) for each observed item. As shown in Table 5 , all the standardized regression weights are highly significant and all above 0.5 , ranging from 0.614 to 0.911, indicating acceptable validity (Anvuur and Kumaraswamy, 2012).

\section{Please insert Table $<5>$ here}

An alternative, and stricter test, is to use the average variance extracted (AVE), where AVE $>0.5$ indicates satisfactory convergent validity (Fornell \& Larcker, 1981). In this case, the average SMCs of the items in the measurement model is the AVE of the construct (Xiong et al 2014). The SMCs of the observed variables range from 0.377 to 0.830 (mean $=0.585$, $\mathrm{SD}=0.128$ ) and, except for PC (AVE=0.492), the AVEs are all larger than 0.5, which is taken mean that convergent validity is marginally acceptable. Additionally, as shown in Table 6, the model fit is very good with $\chi^{2}=54.085\left(\mathrm{df}=48, \chi^{2} / \mathrm{df}=1.127<5, \mathrm{p}=0.253>0.05\right)$.

\section{Please insert Table $<6>$ here}

\section{Structural equation modeling}

As a good model fit is obtained in the CFA $\left(\chi^{2} / \mathrm{df}=1.127<5\right)$, the correlations between constructs are now replaced by the hypothesized causal relationships. The final SEM model is illustrated in the Figure 2, which shows that project definition (PD) has a significant direct impact on design quality (DQ) and project performance (PP), and a significant indirect impact on project communication (PC) through design quality (DQ). Additionally, project communication (PC) has a significant direct impact on project performance, and design quality has a significant indirect impact on project performance through project communication. Table 7 summarizes these direct and indirect casual relationships between constructs. The p values presented in the parentheses are obtained by bootstrapping.

\section{Please insert Fig $<2>$ here}

\section{Please insert Table $<7>$ here}




\section{Findings and discussion}

Path hypothesis 1 (project definition has a positive direct effect on project performance) is supported at $\beta=0.378(\mathrm{p}<0.001)$. Many studies have illustrated a correlation between clear project definition and project performance (e.g. Songer and Molenaar, 1997; Känkönen, 1999; Chan et al. 2001; Cho et al., 2009; Cano and Lidon, 2011; Fageha and Aibinu, 2013). The finding of path hypothesis 1 not only aligns with intuition in that a clear project definition is key to project success and an increased effort in project definition leads to improved project performance in terms of cost, schedule and operational characteristics (Griffith et al., 1999; Hanna and Skiffington, 2010; Yang et al., 2012), but also proves a causal relationship between project scope and project performance with empirical evidence. Therefore, project owners need to clearly define the project before leave the project to contractors. Especially in design-build projects, as project owners hand over the project to design-builder at early project stage, normally after schematic design, it is suggested that project owners provide detailed performance and technical specifications in request for proposals. For those without sufficient internal design resources, service from external consultant should be employed to ensure a clear project definition.

Path hypothesis 2 (project definition has a positive direct effect on design quality) is also supported with $\beta=0.573$ ( $\mathrm{p}<0.001)$. According to Cho and Gibson (2001), a weak project definition leads to poor design quality. Gibson and Gebken (2003) also confirm that a clear project definition can enhance design quality by integrating the perspectives of various project participants. Therefore, in the traditional project delivery system, design consultant is normally employed at the early stage of the project to not only help owners define the project scope but also provide design service in the remaining project stage, which will ensure the consistence and quality of design solutions. The causal relationship between project definition and design quality also explain the frequent adoption of novation design-build where the owner stipulates his/her consultant to be engaged by the DB contractor to complete the design. In addition, as both path hypothesis 6 (design quality has a positive direct effect on project communication) and path hypothesis 5 (project communication has a positive direct effect on project performance) are supported with $\beta=0.657$ and 0.367 respectively at $p$ $<0.001$, it implies that project definition has a significant indirect impact on project performance through design quality and project communication, which is confirmed by the 
subsequent bootstrapping analysis with $\mathrm{p}=.034$ less than .05. Additionally, given the importance of project communication to the project performance (a significant positive impact as shown in Path hypothesis 5), project contractors should not only establish effective communication internally but also externally with project owners, design consultants and subcontractors. Thus relational contracting ranging from partnering to integrated project delivery is recommended to promote the collaboration between different project stakeholders.

The hypothesized positive relationship between project definition and project communication (path hypothesis 4 ) is rejected at $\mathrm{p}=0.184$, however, the positive direct impact is supported with $\beta=0.160$. This is confirmed by Cho and Gibson's (2001) observation that a clear project definition assists in communication among project participants. Additionally, as project design quality has a significant positive impact on project communication along with a significant relationship between project definition and design quality (path hypothesis 2), it indicated that project definition has a significant indirect impact on project communication, which means the impact of project definition on project communication is strongly dependent upon the quality of design. Given the importance of design quality, it is of extreme importance for the design consultant to improve the constructability of design solutions, and provide design flexibility to accommodate future changes. Especially in traditional designbid-build projects, as design and construction are undertaken by separate entities, improved constructability and flexibility of design solutions will greatly improve the interaction between project owners, design consultant and contractors, and enable necessary design changes in the late project stage and reduce the related cost significantly.

Although there is no direct relationship between design quality and project performance (path hypothesis 3), design quality has a significant indirect positive impact on final project performance through project communication. Construction projects involve a number of disciplines collaborating for a period of time during project development. In the traditional project procurement method, the dominant method in the Malaysian construction market (Masrom 2012), the architect completes most of the design before handing the project to other project participants. Design quality can affect project communication significantly (path hypothesis 6) as poor design quality results in unwanted design changes and disputes and liability claims (Anumba et al., 1997). As project communication has a positive direct effect on project and team performance (path hypothesis 5), as evidenced by a number of studies (e.g. Pinto and Pinto, 1990; Patrashkova-Volzdoska et al., 2003), it means that design 
quality affects project performance significantly through project communication. This finding highlights the importance of the role that design consultant plays in the construction project delivery. It provides a number of practical implications. For project owners, the selection of design consultant should be qualification based rather than lowest price in order to obtain the qualified design service. For contractors, effective communication with design consultant is of vital importance. In design-build projects, a novation contract, where design team is selected by the client and subsequently novated to the contractor, can be a feasible way to improve the communication between design consultant and DB contractor as it ensures a greater consistency in design as the design team originally appointed remains throughout the project. Additionally, design-build contractors with sufficient internal design resources are more likely to have better design quality and effective project communication due to the comparatively higher level of team integration within in the same organization.

\section{Conclusions}

Clarity of project definition is widely accepted as critical for the success of construction projects. The focal point of this paper has been to examine the causal relationship between project definition and project success. A conceptual model, involving project definition, project performance, design quality and project communications, was developed and tested using structural equation modeling. The results indicate that project definition has a significant direct impact on project performance. This empirical result improves the knowledge from previous qualitative studies (i.e. the existence of correlation between project definition and project performance), accords with some commonly accepted professional standards (e.g. PMI Guide to the Project Management Body of Knowledge) and the experiences and expectations of most construction industry practitioners (Dvir et al., 2003). Furthermore, project definition has a significant indirect impact on project performance through design quality and project communication, confirming the importance of clear project definition on the success of construction projects. Additionally, given the significant impact of project definition and design quality on the final project outcome, the role of the design consultant in the traditional project procurement method has been highlighted.

The primary contribution of this paper has been to reveal the casual relationships between project definition, project performance, design quality and project communication with em- 
pirical evidence from the Malaysian construction market. This provides quantitative confirmation of the more general statements made in the literature from around the world and therefore adds to and improves existing knowledge. Furthermore, as lack of the clarity of project definition is a very common occurrence in construction projects globally, these findings have important ramifications for all construction projects in expanding and clarifying existing knowledge on what is needed for the successful delivery of construction projects. Further research could extend the model developed here into a more comprehensive treatment including contributions from other stakeholders, such as owners and design consultants.

\section{Acknowledgements}

The data used in this paper is from Dr. Asrul Nasid Masrom's PhD project entitled “Developing a predictive contractor satisfaction model for construction projects”.

\section{References}

Alshawi, M., and Underwood, J. (1996). Improving the constructability of design solutions through an integrated system. Engineering, Construction and Architectural Management, $3(1 / 2), 47-67$.

Anumba, C.J., Baron G., and Evbuomwan N.F.O (1997). Communications issues in concurrent life-cycle design and construction, BT Technology Journal, 15 (1), 209-216

Anvuur, A., and Kumaraswamy, M. (2012). Measurement and antecedents of cooperation in construction. Journal of Construction Engineering and Management, 138(7), 797-810.

Assaf, S. A., and Al-Hejji, S. (2006). Causes of delay in large construction projects. International Journal of Project Management, 24(4), 349-357.

Atkinson R., Crawford L., and Ward S. (2006). Fundamental uncertainties in projects and the scope of project management. International Journal of Project Management, 24 (2006) 687-698.

Bagozzi, R. P., and Yi, Y. (2012). Specification, evaluation, and interpretation of structural equation models. Journal of the Academy of Marketing Science, 40(1), 8-34. 
Ballard G. and Zabelle T. (2000). Project definition. Whitepaper \#9, Lean Construction Institute, USA. http://www.leanconstruction.org

Belout A. and Gauvreau C. (2004) Factors influencing project success: the impact of human resource management. International Journal of Project Management, 22 (1), 1-11.

Byrne, B. M. (2010). Structural equation modeling with AMOS: basic concepts, applications, and programming. Routledge, New York.

Cano J.L. and Lidon I. (2011). Guided reflection on project definition. International Journal of Project Management, 29 (5), 525-536.

Chan, A., Ho, D., and Tam, C. (2001). Design and Build Project Success Factors: Multivariate Analysis. Journal of Construction Engineering and Management, 127(2), 93-100.

Chen, L., \& Fong, P. S. (2012). Revealing performance heterogeneity through knowledge management maturity evaluation: A capability-based approach. Expert Systems with Applications, 39(18), 13523-13539.

Cheng, J., Proverbs, D. G., \& Oduoza, C. F. (2006). The satisfaction levels of UK construction clients based on the performance of consultants: Results of a case study. Engineering, Construction and Architectural Management, 13(6), 567-583.

Cheung, S. O., and Chow, P. T. (2011). Withdrawal in construction project dispute negotiation. Journal of Construction Engineering and Management, 137(12), 1071-1079.

Cho, C. S. and Gibson, G. E. (2001). Building project scope definition using project definition rating index, Journal of Architectural Engineering 7(4): 115-125.

Cho, K., Hong, T., and Hyun, C. (2009). Effect of project characteristics on project performance in construction projects based on structural equation model. Expert Systems with Applications, 36(7), 10461-10470. 
Chritamara S., Ogunlana, S.O., Bach N.L. (2001) Investigating the effect of initial scope establishment on the performance of a project through system dynamics modeling, Engineering, Construction and Architectural Management, 8 (5/6), 381-392.

Construction Industry Institute (1995). Pre-project planning handbook. Special publication 39-2. Texas: Construction Industry Institute.

Dumont, P.R., Gibson. G.E., Fish J.R. (1997). Scope management using project definition rating index. Journal of Management in Engineering, 13 (5): 54-60.

Dvir, D., Raz T., and Shenhar A.J. (2003). An empirical analysis of the relationship between project planning and project success. International Journal of Project Management, 21 (2), 89-95.

Fageha M.K. and Aibinu A.A (2013) Managing project scope definition to improve stakeholders' participation and enhance project outcome. Procedia - Social and Behavioral Sciences, 74 ( 2013 ) $154-164$.

Fornell, C., and Larcker, D. (1987). A second generation of multivariate analysis: classification of methods and implications for marketing research. Review of Marketing, 1, 407-450.

Fornell, C., and Larcker, D. F. (1981). Evaluating structural equation models with unobservable variables and measurement error. Journal of Marketing Research, 39-50.

Gann D., Salter A., and Whyte, J. (2003). Design Quality Indicator as a tool for thinking, Building Research \& Information, 31 (5), 318-333.

Gibson E. and Gebken R. (2003) Design quality in pre-project planning: applications of the Project Definition Rating Index, Building Research \& Information, 31:5, 346-356.

Griffith, A. F., Gibson, G. E., Hamilton, M. R., Tortora, A. L., and Wilson, C. T. (1999). Project success index for capital facility construction projects. J. Perf. Constr. Fac., ASCE, 13(1), 39-45. 
Hair, J. F., Ringle, C. M., and Sarstedt, M. (2012). Partial least squares: the better approach to structural equation modeling? Long Range Planning, 45, Issues 5-6, 312-319

Hanna, A. and Skiffington, M. (2010). Effect of preconstruction planning effort on sheet metal project performance. Journal of Construction Engineering and Management, 136(2), 235-241.

Känkönen, K., (1999). Multi-character model of the construction project definition process. Automation in Construction, 8 (6), 625-632.

Keline, R. B. (2005). Principles and practice of structural equation modeling. The Guilford Press Inc., New York.

Keller K.L. (2001) Mastering the marketing communications mix: micro and macro perspectives on integrated marketing communication programs. Journal of Marketing Management, 17 (7-8), 819-847.

Masrom, M. A. N. (2012). Developing a predictive contractor satisfaction model (CoSMo) for construction projects. PhD thesis, Queensland University of Technology.

Park, S.H., 2009.Whole life performance assessment: critical success factors. Journal of Construction Engineering Management 135 (11), 1146-1161.

Patrashkova-Volzdoska, R.R., McComb, S.A., Green S.G. (2003) Examining a curvilinear relationship between communication frequency and team performance in crossfunctional project teams. IEEE Transactions on Engineering Management, 50 (3), 262269.

Pinto M.B., and Pinto J.K. (1990) Project team communication and cross-functional cooperation in new program development. Journal of Product Innovation Management, 7 (3), 200-212. 
Project Management Institute (2000). A Guide to the Project Management Body of Knowledge, PMI, Newton Square, PA.

Pulaski M.H., and Horman M.J. (2005) Organizing Constructability Knowledge for Design. Journal of Construction Engineering and Management,131 (8), 911-919.

Quatman, G.W., Dhar, R., (2003) The Architect's Guide to Design-Build Services, John Wiley and Sons, Hoboken, New Jersey.

Sambasivan, M., and Soon, Y. W. (2007). Causes and effects of delays in Malaysian construction industry. International Journal of Project Management, 25(5), 517-526.

Shah, R., \& Goldstein, S. M. (2006). Use of structural equation modeling in operations management research: Looking back and forward. Journal of Operations Management, 24, 148-169.

Soetanto, R., \& Proverbs, D. G. (2004). Intelligent models for predicting levels of client satisfaction. Journal of Construction Research, 5(2), 233-253.

Songer A.D. and Molenaar K.R., (1997) Project characteristics for successful public-sector design-build, Journal of Construction Engineering and Management, 123 (1), 34-40.

Song L.G., and AbouRizk S.M. (2005) Quantifying engineering project scope for productivity modeling. Journal of Construction Engineering and Management, 131 (3), 360-367.

Tang, S. L., Ming, L., \& Chan, Y. L. (2003). Achieving Client Satisfaction for Engineering Consulting Firms. Journal of Management in Engineering, 19(4), 166-172.

Turner J.R. and Muller R. (2004) Communication and co-operation on projects between the project owner as principal and the project manager as agent. European Management Journal, 22 (3), 327-336. 
Wang W.T., and Ko N.Y. (2012) Knowledge sharing practices of project teams when encountering changes in project scope: A contingency approach. Journal of Information Science 38(5) 423-441.

Wang, X., and Huang, J. (2006). The relationships between key stakeholders' project performance and project success: Perceptions of Chinese construction supervising engineers. International Journal of Project Management, 24(3), 253-260.

Xia, B., and Chan, A. (2010) Key competences of design-build clients in China. Journal of Facilities Management, 8(2), 114-129.

Xia, B., Chan, A., Molenaar, K., and Skitmore, M. (2012a). Determining the appropriate proportion of owner-provided design in design-build contracts: content analysis approach. Journal of Construction Engineering and Management, 138(9), 1017-1022.

Xia, B., Chan, A., Zuo, J., \& Molenaar, K. (2012b) Analysis of selection criteria for designbuilders through the analysis of Request for Proposals (RFPs). Journal of Management in Engineering, 29(1), pp. 19-24.

Xia, B., Chan, A., Molenaar, K., and Skitmore, M. (2012c) Determining the Appropriate Proportion of Owner-Provided Design in Design-Build Contracts: Content Analysis Approach. Journal of Construction Engineering and Management, 138(9), 1017-1022.

Xia, B., Molenaar, K., Chan A., Skitmore M., and Zuo J. (2013) Determining the optimal proportion of design in design-build request for proposals (RFPs). Journal of Construction Engineering and Management, 139(6), 620-627

Xiong, B., Skitmore, M., Xia, B., Masrom, M. A., Ye, K., and Bridge, A. (2014). Examining the influence of participant performance factors on contractor satisfaction: A structural equation model. International Journal of Project Management, 32(2), 482-491. 
Yang , L.R., Chen J.H., \& Huang, C.F. (2012) Requirements definition and management practice to improve project outcomes, Journal of Civil Engineering and Management, 18(1), 114-124.

Yang, J.-B., \& Peng, S.-C. (2008). Development of a customer satisfaction evaluation model for construction project management. Building and Environment, 43(4), 458-468.

Yu, A. T., Shen, Q., Kelly, J., and Hunter, K. (2006). Investigation of critical success factors in construction project briefing by way of content analysis. Journal of Construction Engineering and Management, 132(11), 1178-1186. 
Table 1. Measurement constructs and items

\begin{tabular}{|c|c|c|c|c|c|}
\hline Constructs & No. & Items & Main sources & Mean & SD \\
\hline \multirow{3}{*}{$\begin{array}{l}\text { Project defini- } \\
\text { tion (PD) }\end{array}$} & Q1 & $\begin{array}{l}\text { Quality of project brief (e.g. needs } \\
\text { and requirements) }\end{array}$ & \multirow{3}{*}{$\begin{array}{l}\text { Känkönen (1999); Assaf } \\
\text { and Al-Hejji (2006); } \\
\text { Atkinson et al. (2006); } \\
\text { Park (2009); Cho et al., } \\
\text { (2009) }\end{array}$} & 3.700 & 0.846 \\
\hline & Q2 & Completeness of project brief & & 3.717 & 0.852 \\
\hline & Q3 & Certainty of project brief & & 3.650 & 0.913 \\
\hline \multirow{3}{*}{$\begin{array}{l}\text { Design quality } \\
\text { (DQ) }\end{array}$} & Q4 & Design constructability & \multirow{3}{*}{$\begin{array}{l}\text { Alshawi and Underwood } \\
\text { (1996); Pulaski and } \\
\text { Horman 2005; Park } \\
\text { (2009); Cho et al., } \\
\text { (2009); Masrom (2012) }\end{array}$} & 3.625 & 0.861 \\
\hline & Q5 & Comprehensiveness of design & & 3.617 & 0.832 \\
\hline & Q6 & $\begin{array}{l}\text { Flexibility of design to accommodate } \\
\text { changes }\end{array}$ & & 3.608 & 0.873 \\
\hline \multirow{3}{*}{$\begin{array}{l}\text { Project com- } \\
\text { munication } \\
(\mathrm{PC})\end{array}$} & Q7 & $\begin{array}{l}\text { Two- way communication between } \\
\text { participants and your project team }\end{array}$ & \multirow{3}{*}{$\begin{array}{l}\text { Tang et al., 2003; Soetan- } \\
\text { to and Proverbs (2004); } \\
\text { Cheng et al., (2006); } \\
\text { Yang and Peng (2008). }\end{array}$} & 3.667 & 0.813 \\
\hline & Q8 & $\begin{array}{l}\text { Collaborative work between partici- } \\
\text { pants and your project team }\end{array}$ & & 3.617 & 0.791 \\
\hline & Q9 & $\begin{array}{l}\text { Quality of relationship between sub- } \\
\text { contractors and your project team }\end{array}$ & & 3.575 & 0.816 \\
\hline \multirow{3}{*}{$\begin{array}{l}\text { Project per- } \\
\text { formance (PP) }\end{array}$} & Q10 & Project cost performance & \multirow{3}{*}{$\begin{array}{l}\text { Griffith et al. (1999); } \\
\text { Chan et al. (2001); Han- } \\
\text { na and Skiffington } \\
\text { (2010); Wang and Ko } \\
\text { (2012) }\end{array}$} & 3.600 & 0.834 \\
\hline & Q11 & Schedule performance & & 3.450 & 0.977 \\
\hline & Q12 & Construction quality performance & & 3.692 & 0.797 \\
\hline
\end{tabular}


Table 2 Summary of respondents profiles

\begin{tabular}{|l|l|c|}
\hline \multirow{3}{*}{ Profiles } & Categories & Frequency \\
\hline \multirow{4}{*}{ Organization size } & Large companies & $66(55 \%)$ \\
\cline { 2 - 3 } & Small to medium companies & $54(45 \%)$ \\
\hline \multirow{5}{*}{ Project procurement method } & Design, bid and build & $77(64.2 \%)$ \\
\cline { 2 - 3 } & Design and build & $27(22.5 \%)$ \\
\cline { 2 - 3 } & CM & $11(9.2 \%)$ \\
\cline { 2 - 3 } & Others & $5(4.2 \%)$ \\
\hline \multirow{5}{*}{ Experience } & $1-5$ years & $18.3 \%$ \\
\cline { 2 - 3 } & $6-10$ years & $26.7 \%$ \\
\cline { 2 - 3 } & $11-15$ years & $23.3 \%$ \\
\cline { 2 - 3 } & $16-20$ years & $10.0 \%$ \\
\cline { 2 - 3 } & More than 20 years & $21.7 \%$ \\
\hline
\end{tabular}


Table 3 ANOVA test results in terms of project size and procurement methods

\begin{tabular}{ccccc}
\hline Items & Q1-3 & Q4-6 & Q7-9 & Q10-12 \\
\hline $\begin{array}{c}\text { PCs (variance ex- } \\
\text { plained) } \\
\text { KMO }\end{array}$ & PD (78.451\%) & DQ (73.911) & PC (66.088\%) & PP (68.429\%) \\
$\begin{array}{c}\text { Bartlett's Test of Sphe- } \\
\text { ricity }\end{array}$ & 0.689 & 0.694 & 0.689 & 0.679 \\
$\begin{array}{c}\text { p value by ANOVA } \\
\text { (project size) }\end{array}$ & 0.000 & 0.000 & 0.000 & 0.000 \\
$\begin{array}{c}\text { p value by ANOVA } \\
\text { (procurement methods) }\end{array}$ & 0.730 & 0.937 & 0.894 & 0.344 \\
\hline
\end{tabular}


Table 4. Results of reliability tests

\begin{tabular}{cccccc}
\hline Variables & All 12 & Q1-3 & Q4-6 & Q7-9 & Q10-12 \\
\hline Cronbach's alpha value & 0.884 & 0.861 & 0.822 & 0.743 & 0.767 \\
\hline
\end{tabular}


Table 5: Standardized regression weights and SMCs

\begin{tabular}{ccccc}
\hline \multirow{2}{*}{ Item } & \multicolumn{2}{c}{ Standardized regression weights } & SMC \\
\cline { 2 - 5 } & PD & DQ & PC & $0.623(0.423,0.788)$ \\
\hline Q1 & $0.789(0.650,0.888)$ & & $0.830(0.709,0.939)$ \\
Q2 & $0.911(0.842,0.969)$ & & $0.621(0.466,0.758)$ \\
Q3 & $0.788(0.683,0.871)$ & & & $0.626(0.461,0.761)$ \\
Q4 & $0.791(0.679,0.872)$ & $0.724(0.617,0.824)$ & $0.754(0.597,0.885)$ \\
Q5 & $0.868(0.773,0.941)$ & $0.715(0.581,0.818)$ & $0.481(0.345,0.654)$ \\
Q6 & $0.694(0.588,0.809)$ & & $0.525(0.381,0.679)$ \\
Q7 & & & $0.662(0.516,0.797)$ & $0.439(0.266,0.635)$ \\
Q8 & & & $0.773(0.644,0.869)$ & $0.597(0.415,0.756)$ \\
Q9 & & & $0.795(0.691,0.890)$ & $0.633(0.478,0.792)$ \\
Q10 & & & $0.614(0.479,0.740)$ & $0.377(0.230,0.547)$ \\
\hline
\end{tabular}

Note: The values in parentheses are the 90 percentile confidence interval values obtained by 1000 bootstrap sample. All estimates are highly significant at $\mathrm{p}<0.001$. 
Table 6. Goodness of fit

\begin{tabular}{cccc}
\hline Goodness of fit measure & Criteria standard & CFA & SEM-final \\
\hline$p$ level for $\chi 2$ test & $>0.05$ & 0.253 & 0.234 \\
$\chi^{2} / \mathrm{df}$ & $<5.0$ & 1.127 & 1.139 \\
Absolute fit & & & \\
GFI & $>0.9$ & 0.933 & 0.930 \\
AGFI & $>0.8$ & 0.891 & 0.888 \\
RMSEA & $<0.08$ & 0.033 & 0.034 \\
SRMR & $<0.08$ & 0.047 & 0.050 \\
RMR & $<0.05$ & 0.034 & 0.035 \\
Incremental fit & & & \\
CFI & $>0.9$ & 0.990 & 0.989 \\
TLI & $>0.9$ & 0.986 & 0.985 \\
Parsimonious fit & & & \\
PNFI & $>0.5$ & 0.669 & 0.681 \\
PGFI & $>0.5$ & 0.574 & 0.584 \\
\hline
\end{tabular}


Table 7. Direct, indirect and total effects between factors

\begin{tabular}{|c|c|c|c|c|}
\hline Effect type & Factors & PD & DQ & PC \\
\hline \multirow{4}{*}{ Standardized direct effects } & $\mathrm{DQ}$ & $0.573(\mathrm{p}=0.002)$ & 0 & 0 \\
\cline { 2 - 5 } & $\mathrm{PC}$ & $0.16(\mathrm{p}=0.369)$ & $0.657(\mathrm{p}=0.002)$ & 0 \\
\cline { 2 - 5 } & $\mathrm{PP}$ & $0.378(\mathrm{p}=0.045)$ & 0 & $0.367(\mathrm{p}=0.034)$ \\
\hline \multirow{3}{*}{ Standardized indirect effects } & $\mathrm{DQ}$ & 0 & 0 & 0 \\
\cline { 2 - 5 } & $\mathrm{PC}$ & $0.377(\mathrm{p}=0.002)$ & 0 & 0 \\
\cline { 2 - 5 } & $\mathrm{PP}$ & $0.197(\mathrm{p}=0.034)$ & $0.241(\mathrm{p}=0.034)$ & 0 \\
\hline \multirow{3}{*}{ Standardized total effects } & $\mathrm{DQ}$ & $0.573(\mathrm{p}=0.002)$ & 0 & 0 \\
\cline { 2 - 5 } & $\mathrm{PC}$ & $0.536(\mathrm{p}=0.002)$ & $0.657(\mathrm{p}=0.002)$ & 0 \\
\cline { 2 - 5 } & $\mathrm{PP}$ & $0.575(\mathrm{p}=0.002)$ & $0.241(\mathrm{p}=0.034)$ & $0.367(\mathrm{p}=0.034)$ \\
\hline
\end{tabular}

Note: The $\mathrm{p}$ values presented in the parentheses are obtained by 1000 bootstrapping. 